\title{
Kompetencje kluczowe w edukacji polonistycznej a działalność innowacyjna szkół - przykład rozwiązań dydaktycznych
}

\author{
Key competences in Polish education \\ and the innovative activity of schools - \\ an example of didactic solutions
}

Summary: The aim of the article is to discuss the issue of key competences and to show examples of didactic solutions related to their education in the scope of Polish language education and educational work. The author focuses primarily on social and communication competences. She presents the assumptions of pedagogical innovation, which assumes youth project activities. She also points out the benefits of casting students as explorers, seekers, and creators.

Keywords: key competences, social competences, communication competences, didactic innovations

Kształcenie kompetencji kluczowych to jeden z najważniejszych celów we wszystkich systemach kształcenia w Europie ${ }^{1}$. Jest to związane z zaleceniem, jakie przyjęli Parlament Europejski i Rada Unii Europejskiej w 2006 roku w sprawie kompetencji kluczowych w procesie uczenia się przez całe życie. Dokument ten wskazywał potrzebę rozwijania „oferty kompetencji kluczowych dla wszystkich w ramach ich strategii uczenia się przez całe życie, w tym stra-

${ }^{1}$ Zob. Kompetencje kluczowe. Realizacja koncepcji na poziomie szkolnictwa obowiazkowego. Red. A. Smoczyńska. Warszawa 2005. 
tegii osiągnięcia powszechnej alfabetyzacji”². Opublikowano w nim listę ośmiu kompetencji ${ }^{3}$.

Z uwagi na liczne zmiany społeczne i gospodarcze na światowym rynku pracy, które związane są między innymi z automatyzacją, cy fryzacją i przemianami cywilizacyjnymi oraz polityką socjalną, w roku 2018 Rada Unii Europejskiej wydała nowe zalecenie, które weryfikowało i uzupełniało poprzedni dokument, dostosowując go do aktualnych potrzeb ${ }^{4}$. Opierając się na przywołanym akcie prawnym, można wyróżnić obowiązujące dziś kompetencje kluczowe, na które składają się:

— kompetencje w zakresie rozumienia i tworzenia informacji,

— kompetencje w zakresie wielojęzyczności,

- kompetencje matematyczne oraz kompetencje w zakresie nauk przyrodniczych, technologii i inżynierii,

- kompetencje cyfrowe,

- kompetencje osobiste, społeczne i w zakresie umiejętności uczenia się,

- kompetencje obywatelskie,

— kompetencje w zakresie przedsiębiorczości,

— kompetencje w zakresie świadomości i ekspresji kulturalnej.

Każda z wymienionych kompetencji stanowić ma połączenie wiedzy ${ }^{5}$, umiejętności ${ }^{6}$ i postaw ${ }^{7}$. Ponadto mają się one cechować dynamicznym charakterem i podlegać zmianom zarówno w wymiarze ilościowym, jak i jakościowym. Wiesława Żuchowska zaznacza, że

ćwiczone i sprawdzane w doświadczeniu nie są już tym samym, co na początku kształcenia. Nie tylko przekształcają się w sprawność, ale obrastają refleksją i świadomością, pozwalają tworzyć uogólnienia, stają się źródłem nowej wiedzy. W myśleniu o dydaktyce kompetencje stają się nie celem wyłącznie, ale narzędziem uczenia się, podstawą [...] dalszego

${ }^{2}$ Zob. Zalecenie Parlamentu Europejskiego i Rady z dnia 18 grudnia 2006 roku. Dz.U. L 394 z 30.12.2006, s. 10 .

${ }^{3}$ Porozumiewanie się w języku ojczystym, porozumiewanie się w językach obcych, kompetencje matematyczne i podstawowe kompetencje naukowo-techniczne; kompetencje informatyczne, umiejętność uczenia się, kompetencje społeczne i obywatelskie, inicjatywność i przedsiębiorczość, świadomość i ekspresja kulturalna.

${ }^{4}$ Zob. Zalecenie Rady Unii Europejskiej z dnia 22 maja 2018 r. w sprawie kompetencji kluczowych w procesie uczenia się przez całe życie (2018/C189/01). https://eur-lex.europa.eu/legalcontent/PL/TXT/PDF/?uri=CELEX:32018H0604(01)\&from=EN [data dostępu: 31.03.2020].

${ }^{5}$ Fakty i liczby, pojęcia, idee i teorie, które są już ugruntowane i pomagają zrozumieć określoną dziedzinę lub zagadnienie.

${ }^{6}$ Zdolność i możliwość realizacji procesów bądź korzystania z dostępnej wiedzy do osiągania wyników.

${ }^{7}$ Gotowość i skłonność do działania bądź reagowania na idee, osoby lub sytuacje. 
kształcenia i wychowania. Można je rozumieć jako niezbywalny element kultury uczenia się 8 .

Kompetencje kluczowe wydają się niezbędne dla człowieka, który chce w pełni uczestniczyć w życiu społeczeństwa informacyjnego. Warto jednak przywołać koncepcję Lecha Zachera zakładającego, że współczesne społeczeństwo przekształca się w społeczeństwo wiedzy. Powoduje to, że obecnie istotniejsze od ilości stają się jakość informacji, dostępność i szybkość przetwarzania. Dochodzi do regulacji informacji i wprowadzania rozumnego ładu informacyjnego oraz ,tworzenia się nowego substratu intelektualnego jednostek, grup, społeczności, narodu, ludzkości"9. W myśl tej koncepcji powinno zatem dojść do zmian społecznych, dzięki którym społeczeństwa staną się roztropne, rozważne i mądre ${ }^{10}$. Kształcenie kompetencji kluczowych ma wspierać opisywany proces zmian.

Kształcenie wymienionych obszarów trwać ma przez całe życie, w związku z czym stały się one punktem obowiązkowym w pracy dydaktycznej na wszystkich poziomach kształcenia we wszystkich typach szkół i przedszkoli. Analiza Podstawy programowej kształcenia ogólnego ${ }^{11}$, kierunków polityki oświatowej oraz obszarów nadzoru pedagogicznego i ewaluacji z lat 2015-2020 wskazuje, że założenia te zostały uwzględnione w polskich szkołach. W zdecydowanej większości ujęte są w ogólnych celach kształcenia zawartych w Podstawie programowej... ${ }^{12}$. Umiejscowienie obszarów spójnych z kompetencjami kluczowymi we wstępie dokumentu świadczy o tym, że ich kształcenie stanowi nadrzędny cel edukacji, którego osiągnięcie wspomagać powinni wszyscy nauczyciele niezależnie od nauczanego przedmiotu. Warto dodać, że realizację tych założeń na bieżąco kontrolują organy nadzoru pedagogicznego.

Wydaje się jednak, że mimo opublikowania wykazu kompetencji kluczowych w roku 2006 dopiero od roku 2018 podkreślenie wagi opisywanych kompetencji, ich kształcenie i przede wszystkim dokumentowanie wszelkich działań z nimi związanych stały się jednym z priorytetów polskich szkół. Nie oznacza to, że kompetencje te nie były kształcone wcześniej. Wręcz przeciwnie, obsza-

${ }^{8}$ Zob. W. Żuchowska: Do czego dydaktykom potrzebne jest pojęcie kompetencji. „Nowa Polszczyzna" 1999, nr 1.

9 J. Goćkowski, K.M. Machowska: Społeczeństwo wiedzy a społeczeństwo informatyczne. W: Społeczeństwo informatyczne. Szansa czy zagrożenie. Red. B. Chyrowicz. Lublin 2003, s. 106.

${ }^{10}$ Zob. L.W. Zacher: Od społeczeństwa informacji do społeczeństwa wiedzy. Społeczeństwo informacyjne. Wizja czy rzeczywistość?. Kraków 2004.

${ }^{11}$ Podstawa programowa kształcenia ogólnego. https://podstawaprogramowa.p1/ [data dostępu: 30.03.2020].

12 Warto zaznaczyć, że wcześniejsze dokumenty oświatowe również uwzględniały obszary wskazywane jako kompetencje kluczowe. Por. N. Cieślar, J. Samsel-Opalla: Pojęcie kompetencji kluczowych w Podstawie programowej. „Nauczyciel i Szkoła” 2010, nr 1-2, s. 77—82. 
ry w nich wymienione uwzględniano w procesie kształcenia od lat. Świadczy o tym ich obecność w tzw. starej podstawie programowej czy we wprowadzeniu programu operacyjnego Kapitał Ludzki realizowanego w latach 2007-2013. Samo pojęcie kompetencji kluczowych i uaktualnienie zakresu jego znaczenia stały się niezwykle istotne w związku z nowym zaleceniem. Świadczą o tym obowiązkowe szkolenia z zakresu kompetencji kluczowych organizowane we wszystkich placówkach, pojawienie się licznych zakładek, wpisów i publikacji na stronach internetowych szkół związanych z kształceniem kompetencji kluczowych czy tworzenie obowiązkowych konspektów lekcji, które stanowić mają dokument potwierdzający ich kształcenie. $Z$ jednej strony potwierdza to nadmierną biurokrację wciąż obecną w szkolnictwie, z drugiej jednak — świadczy o dostrzeganiu potrzeby kształcenia wybiegającego ponad zagadnienia przedmiotowe, łączenie różnych dziedzin i obszarów wiedzy i umiejętności oraz chęć twórczego i aktywnego współdziałania uczniów i nauczycieli.

Jedną z form działania często wykorzystywaną w procesie kształcenia kompetencji kluczowych jest wprowadzanie innowacji pedagogicznych. Dzieje się tak za sprawą wprowadzenia ustawy Prawo oświatowe, która zakłada, że innowacyjność jest integralnym elementem działalności szkoły. Ustawa ta zniosła wymogi formalne warunkujące realizację innowacji, co wpłynęło na wyzwolenie kreatywności uczniów i nauczycieli ${ }^{13}$. W niniejszym opracowaniu omówiona zostanie innowacja pt. Współdziałanie? To wyzwanie! Kształcenie kompetencji spotecznych $i$ komunikacyjnych $w$ różnorodnych sytuacjach zadaniowych ${ }^{14}$. Innowacja ta stanowi przykład rozwiązania dydaktycznego, którego celem jest kształcenie kompetencji kluczowych ze szczególnym naciskiem na kompetencje osobiste i społeczne oraz kompetencje w zakresie rozumienia i tworzenia informacji.

Terminu kompetencje społeczne użył po raz pierwszy w 1959 roku Robert White. Psycholog ten zdefiniował je jako umiejętności, które pozwalają na skuteczną interakcję $\mathrm{z}$ otoczeniem ${ }^{15}$. Krystyna Skarżyńska określa je jako „umiejętności osiągania celów społecznych i jednostkowych z jednoczesnym zachowaniem dobrych stosunków z partnerami interakcji”" ${ }^{16}$. Inni zakładają natomiast, że są to różnorodne i złożone umiejętności zapewniające efektywność radzenia sobie w sytuacjach społecznych. Anna Matczak podkreśla przy tym, że są one „wyznacznikiem efektywności funkcjonowania jednostki w rzeczy-

${ }^{13}$ Zob. Ustawa Prawo oświatowe. Dz.U., poz. 2248. https://www.prawo.vulcan.edu.pl/przegdok.asp?qdatprz=akt\&qplikid=4186 [data dostępu: 30.03 .2020 ].

${ }^{14}$ Innowacja opracowana i przeprowadzona została przez M. Kubarek (nauczycielkę języka polskiego) i A. Wójcik (pedagoga szkolnego) w Szkole Podstawowej „OMEGA” w Katowicach w roku szkolnym 2018/2019.

15 Zob. H. Sęk: Spoteczna psychologia kliniczna. Warszawa 2004, s. 74-75.

${ }^{16}$ E. Sternal: Kompetencje spoleczne w obliczu przemian spoleczno-gospodarczych. „Przegląd Pedagogiczny" 2014, nr 2, s. 88. 
wistych sytuacjach życiowych"17. Warto przy tym zaznaczyć, że pojęcie kompetencje społeczne bywa utożsamiane $\mathrm{z}$ inteligencją społeczną i emocjonalną, umiejętnościami społecznymi czy ze zdolnościami do wykonywania określonych czynności ${ }^{18}$. Są one warunkowane cechami osobowości, temperamentem, inteligencją ogólną, społeczną i emocjonalną, a ich nabywanie wymaga tzw. treningu społecznego, którego celem jest podnoszenie efektywności funkcjonowania jednostki. Można je podzielić na: kompetencje twarde (zawodowe) oraz kompetencje miękkie. Do drugiej grupy, która stanowi obszar zainteresowania opisywanej innowacji, zaliczyć należy: umiejętności osobiste (sprawne zarządzanie sobą i swoją pracą, zdolność motywowania samego siebie, zorganizowanie zajęć) oraz umiejętności interpersonalne (komunikowanie się z ludźmi, przekonywanie ich do swoich racji, motywowanie, inspirowanie, zarządzanie zespołami, autoprezentację, radzenie sobie ze stresem, asertywność, negocjacje czy savoir-vivre). Warto podkreślić, że kompetencje te uznaje się za niezwykle przydatne w życiu każdego człowieka niezależnie od wykonywanego zawodu.

Pojęcie komunikacja oznacza natomiast porozumiewanie się czy udzielanie wiadomości (informacji). Polega ona „na wzajemnej wymianie informacji przez partnerów interakcji oraz jest procesem mającym ciągłość i trwającym w czasie" ${ }^{\prime 19}$. Komunikacja ściśle łączy się z aspektem społecznym, gdyż wpływa na tworzenie się wspólnego systemu społecznego ${ }^{20}$. Kompetencje komunikacyjne zakładają zatem zachowania werbalne i pozawerbalne, które są adekwatne do kontekstu. Mogą być oceniane pod kątem trafności, stosowności i skuteczności. Skuteczność zakłada osiągnięcie zamierzonego celu. Trafność i stosowność świadczą natomiast o użyciu środków językowych odpowiednio do sytuacji komunikacyjnej, stosowaniu zasad etykiety językowej etc. Prowadzi to do wniosku, że proces komunikacji jest zależny od wiedzy i umiejętności uczestników aktu komunikacji, ich motywacji oraz kontekstu ${ }^{21}$. Oznacza to, że kształcenie kompetencji komunikacyjnych wymaga zarówno budowania świadomości językowej uczniów, jak i stawiania ich w konkretnych sytuacjach komunikacyjnych.

Prezentowana innowacja pedagogiczna miała na celu kształcenie kompetencji społecznych i komunikacyjnych uczniów klas VI szkoły podstawowej22. W myśl zasad poglądowości wiedzy oraz łączenia teorii z praktyką ${ }^{23}$ wszelkie

${ }^{17}$ A. Matczak: Kwestionariusz kompetencji społecznych. Podręcznik. Warszawa 2001.

${ }_{18}$ E. Sternal: Kompetencje społeczne..., s. 88.

19 M. Sikorski: Kompetencje komunikacyjne nauczycieli. „Colloquium Wydziału Nauk Humanistycznich i Społecznych" 2010, nr 2, s. 157.

${ }^{20}$ Zob. A. Sztejnberg: Komunikacyjne środowisko nauczania i uczenia się. Wrocław 2004, s. 86 .

${ }^{21}$ S.P. Morreale, B.H. Spitzberg, J.K. Barge: Komunikacja między ludźmi. Motywacja, wiedza i umiejętności. Tłum. D. Kobylińska, P. Izdebski, A. Jaworska. Warszawa 2007, s. 22.

22 Łączyła się zatem z kompetencjami w zakresie rozumienia i tworzenia informacji oraz kompetencjami osobistymi, społecznymi i w zakresie umiejętności uczenia się.

${ }^{23}$ Zob. M. Nagajow a: ABC metodyki języka polskiego. Warszawa 1995. 
proponowane rozwiązania miały charakter praktyczny i stawiały uczniów w sytuacjach zadaniowych, nadając im role odkrywców, poszukiwaczy lub twórców. Takie podejście pozwoliło na maksymalne zwiększenie uczniowskiej motywacji do pracy oraz wykazywało praktyczny i pozaszkolny wymiar podejmowanych działań.

Innowacja składała się z następujących etapów:

- wprowadzenia — zapoznania uczniów z tematyką innowacji;

— gry terenowej — treningu kompetencji społecznych;

— omówienia zagadnień teoretycznych i okazjonalnych zadań w ramach treningu kompetencji społecznych — zorganizowania cyklu zajęć poświęconych kompetencjom społecznym i komunikacyjnym;

- projektu uczniowskiego - przygotowania treningu kompetencji społecznych w formie gry terenowej dla uczniów klas młodszych;

- ewaluacji.

Wprowadzenie wiązało się z przeprowadzeniem testu kompetencji społecznych. W tym celu posłużono się testem przygotowanym jako propozycja narzędzia do badania kompetencji społecznych określonych jako wskaźniki rezultatów projektów prowadzonych w ramach Lokalnych Systemów Wsparcia ${ }^{24}$. Podzielony on został na trzy części: samokontrolę i radzenie sobie z agresją, współpracę w grupie i relacje z rówieśnikami oraz wsparcie otoczenia. Uzyskane wyniki testu połączone z obserwacjami nauczycieli dotyczącymi zachowania uczniów pozwoliły wskazać słabe strony kompetencji społecznych uczestników projektu i wyodrębnić obszary wymagające wsparcia oraz treningu.

Gra terenowa była formą treningu kompetencji społecznych i komunikacyjnych ${ }^{25}$. Uczniowie zostali podzieleni na losowo wybrane zespoły kilkuosobowe. Każda z drużyn musiała mieć jeden telefon z zainstalowanym komunikatorem, który umożliwia przesyłanie wiadomości tekstowych, zdjęć i filmów ${ }^{26}$. Po ustaleniu kolejności startu uczniowie wymienili się numerami telefonów. Pierwsza z grup otrzymała mapę wskazującą miejsca, w których znajdowały się punkty kontrolne z zadaniami ${ }^{27}$. Gdy do nich dotarła, musiała kolejnej grupie udzielić instrukcji, jak dotrzeć we wskazane miejsce. Następne drużyny nie otrzymywały mapy, mogły zatem polegać jedynie na instrukcjach wysyłanych przez

${ }^{24}$ Kwestionariusz ankiety wykorzystanej w opisywanej innowacji dostępny jest na stronie: https://centrumwspieraniarodzin.pl/images/uploads/Zalacznik_3_OPZ_1_Kwestionariusz\%20an kiety\%20kompetencji\%20spo\%C5\%82ecznych.pdf [data dostępu: 30.03.2020].

${ }^{25}$ Gra odbywała się w parku Kościuszki w Katowicach, co pozwoliło na przywołanie wydarzeń historycznych związanych z tym miejscem. Tym samym można założyć, że podczas prowadzonych zajęć kształcono dodatkowo elementy kompetencji obywatelskich.

${ }^{26}$ Korzystanie $\mathrm{z}$ telefonu jako narzędzia komunikacji świadczy o kształceniu kompetencji cyfrowych uczniów.

27 Praca z mapą wskazuje kształcenie kompetencji matematycznych oraz kompetencji w zakresie nauk przyrodniczych. 
poprzedników. Komunikaty uczniowie przekazywali w różnej formie (krótkiej wiadomości tekstowej ${ }^{28}$, zdjęcia konkretnego miejsca ${ }^{29}$, rozmowy telefonicznej ${ }^{30}$, zdjęcia narysowanej mapy ${ }^{31}$ lub filmu ${ }^{32}$ ). Każde z poleceń zawierało konkretne wskazówki i wymagania dotyczące tworzonych form wypowiedzi. Ich skuteczność oceniana była natomiast na podstawie tego, czy instruowana grupa dotarła do wyznaczonych punktów. Po dotarciu do celu uczniowie nagrywali filmy, w których odpowiadali na zadawane przez nauczyciela pytania ${ }^{33}$, pozwalające podsumować całość działań ${ }^{34}$. Na tej podstawie uczniowie dostrzegli, że ich komunikaty nie zawsze są skuteczne, bywają mało precyzyjne i chaotyczne ${ }^{35}$. Ponadto zauważyli, że ograniczenia związane z liczbą znaków, formą wypowiedzi i jej czasem znacząco utrudniały im budowanie skutecznych wypowiedzi. Podkreślali też, że działanie w grupie nie zawsze było łatwe. Lepiej współpracę oceniały zespoły, które ustaliły zasady i podzieliły się obowiązkami.

Omówienie zagadnień teoretycznych i wprowadzanie okazjonalnych zadań w ramach treningu kompetencji społecznych odbywało się w ramach lekcji języka polskiego, godzin wychowawczych oraz uroczystości szkolnych. Tematyka prowadzonych zajęć obejmowała następujące zagadnienia:

- pojęcie komunikacji i jej rodzaje;

— stosowność i skuteczność wypowiedzi językowych;

— sztukę autoprezentacji;

— negocjacje i dyskusję jako formy osiągania celu;

- savoir-vivre w języku i zachowaniu;

${ }^{28}$ Pierwsze polecenie wymagające ułożenia krótkiej wypowiedzi pisemnej brzmiało: „Wyślijcie SMS do kolejnej grupy, w którym wyjaśnicie, jak dotrzeć do tego punktu. Wasza wiadomość nie może przekroczyć 100 znaków (w tym wliczamy pauzy)”. Kolejne z poleceń przyjęło formę: „Na dołączonych kartkach napiszcie instrukcję dotarcia do tego punktu. Wasza praca musi składać się z 5 zdań pojedynczych. Zdjęcie gotowego tekstu wyślijcie kolejnej grupie”.

29 „Zróbcie jedno zdjęcie okolicy, w taki sposób, aby kolejna grupa była w stanie na jego podstawie dotrzeć do tego miejsca. Wyślijcie je. Pamiętajcie, że nie możecie dołączyć do wiadomości żadnej dodatkowej informacji”.

${ }_{30}$ „Zadzwońcie do kolejnej grupy i udzielcie jej wskazówek, jak dotrzeć do tego punktu. Wasze połączenie nie może być dłuższe niż 30 sekund".

31 „Na dołączonych kartkach narysujcie plan dotarcia do tego punktu. Możecie używać w nim tylko znaków i symboli — nie można używać słów. Zdjęcie stworzonego schematu prześlijcie kolejnej grupie".

32 „Nagrajcie filmik, w którym poinstruujecie kolejną grupę, jak dotrzeć do tego miejsca. W kadrze może znajdować się tylko jedna osoba (od czubka głowy do ramion). W tle nie mogą znajdować się charakterystyczne miejsca, przedmioty, obiekty itp. Filmik nie może przekroczyć 30 sekund. Gotowe dzieło wyślijcie kolejnej grupie".

33 „Czy otrzymywane instrukcje były czytelne? Jeśli nie, dlaczego? Czy korzystali z pomocy spotkanych ludzi? Co sprawiło im trudność? Jakie funkcje pełnili w zespole? Czego ich nauczyła ta gra?".

${ }^{34}$ Film został zmontowany i zaprezentowany uczniom podczas podsumowania projektu.

${ }^{35}$ Podczas gry tylko jeden zespół dotarł do wszystkich punktów. 
— pojęcie perswazji i manipulacji;

— współpracę w zespole;

— radzenie sobie ze stresem;

- dążenie do celu;

— umiejętność radzenia sobie w trudnych sytuacjach;

- opanowanie umiejętności dobrego komunikowania: asertywności, tolerancji.

Część zadań związana była z obchodami Ogólnopolskiego Tygodnia Bibliotek Szkolnych, między innymi tworzenie wykazów linków do edukacyjnych stron internetowych związanych ze wskazanymi przedmiotami szkolnymi czy robienie zdjęć promujących czytelnictwo w ramach akcji $Z$ książka mi do twarzy. Inne zadania miały związek z Międzynarodowym Dniem Języka Ojczystego. $\mathrm{Z}$ tej okazji uczniowie przeprowadzali akcje promujące język polski. Ich zakres planowali na podstawie fragmentu Ustawy o języku polskim zawartego w podręczniku ${ }^{36}$. Zasady autoprezentacji ćwiczono między innymi podczas pracy nad formami wypowiedzi. Przykładem mogą być programy kulinarne nagrywane przez uczniów w ramach utrwalania zasad tworzenia przepisu kulinarnego.

Zadania proponowane uczniom wymagały współpracy w grupie, planowania pracy, terminowej realizacji zadań, sprawnej komunikacji, kreatywności i korzystania z różnorodnych narzędzi, w tym technologii informacyjno-komunikacyjnych. Każde wykonane zadanie omawiał nauczyciel; wiązało się z samooceną uczniów. Samoocena ta zakładała wskazanie tego, co uznawali za swój sukces, określenie poziomu zaangażowania w projekt oraz przedstawienie trudności, jakie napotkali, sposobów zapobiegania im i rozwiązywania bieżących problemów.

Zadanie, które miało na celu podsumowanie prowadzonych zajęć, polegało na zaplanowaniu i przeprowadzeniu przez młodzież gry terenowej dla uczniów klas V. Uczniowie ustalili z nauczycielem podział na kilkuosobowe grupy odpowiedzialne za przygotowanie zadań w wyznaczonych punktach kontrolnych oraz harmonogram działań (termin przedstawienia propozycji zadań, termin prezentacji potrzebnych materiałów oraz termin przeprowadzenia gry). Ponadto uczniowie wraz z nauczycielem ustalili regulamin gry, instrukcję dla grup oraz punktację za wykonane zadania. Na miejsce gry uczniowie wybrali teren Wojewódzkiego Parku Kultury i Wypoczynku - strefę wolną od ruchu samochodowego, co pozwoliło na bezpieczne przemieszczanie się grup piątoklasistów.

Zadania zaproponowane przez uczniów były różnorodne i wymagały między innymi umiejętności współpracy w zespole, aktywności twórczej, kreatywności, a także sprawnego komunikowania się. Wśród zaproponowanych zadań znalazły się scenki rodzajowe, kalambury, elementy pantomimy, quizy, gry,

${ }^{36}$ Zob. A. Łuczak, A. Murdzek: Język polski. Między nami. Podręcznik dla klasy 6. Gdańsk 2017, s. 113. 
puzzle, a nawet zadania konstruktorskie z wykorzystaniem klocków lego. Każdy punkt zakładał innego rodzaju aktywność, co sprawiało, że uczestnicy byli w pełni zmotywowani i angażowali się w proponowane zadania.

Po zakończeniu gry uczestnicy oceniali zadania, które musieli wykonać. Zwracali przy tym uwagę na to, czy polecenia zostały sformułowane jasno i zrozumiale. Organizatorzy natomiast wskazywali, z jakimi problemami musieli się uporać podczas przeprowadzania zabawy. Wskazywali powody ewentualnych problemów, konfliktów i nieporozumień oraz sposoby ich rozwiązania.

Ewaluacja pozwoliła na podsumowanie wszystkich działań realizowanych w ramach innowacji. Uczniowie stworzyli wykaz tego, czego się nauczyli, w którym wymienili:

— współdziałanie w grupie (umiejętność przydzielania zadań zgodnie z predyspozycjami uczestników, wybór lidera, kontrolę realizowanych zadań, dokonywanie ewaluacji);

— poznanie różnych form komunikacji;

- poszukiwanie kreatywnych rozwiązań;

- stosowanie się do zasad zdrowej rywalizacji;

— wsłuchiwanie się w potrzeby i pomysły innych,

— poszukiwanie dróg wzajemnego zrozumienia;

— działanie pod presją czasu i stresu wynikającego z sytuacji zadaniowej;

- zarządzanie czasem pracy;

- realizowanie celów długoterminowych.

Wskazali też obszary, nad którymi chcą jeszcze pracować. Wśród nich wymienili: rozwiązywanie problemów i konfliktów; budowanie skutecznych komunikatów oraz terminową realizację zadań. Wszystko ujęli w formie plakatu, który został wyeksponowany na terenie szkoły.

Opisana innowacja stanowi propozycję realizacji założeń związanych z kształceniem kompetencji kluczowych. Jej założenia pozwalają na włączanie różnorodnych działań projektowych czy okazjonalnych, dzięki czemu jej wprowadzanie można swobodnie powiązać $\mathrm{z}$ zagadnieniami omawianymi w ramach lekcji języka polskiego czy godzin wychowawczych. Zwraca ona szczególną uwagę na kompetencje społeczne i komunikacyjne, ale umożliwia też wprowadzanie elementów kształtujących inne obszary. Zapewnienie uczniom możliwości decydowania o formie pracy oraz umożliwienie im organizowania działań dla uczniów klas młodszych powodują natomiast, że mają oni poczucie odpowiedzialności i docenienia. To oni bowiem występują w roli ekspertów i organizatorów. Warto dodać, że prowadzona forma zajęć pozwala ponadto na międzyoddziałowe integrowanie uczniów, zapoznanie ich z różnymi formami komunikacji, kształcenie umiejętności dostosowywania formy i sposobu komunikacji do sytuacji oraz ćwiczenie sztuki autoprezentacji i szeroko rozumianych zdolności organizacyjnych. 


\section{Bibliografia}

Cieślar N., Samsel-Opalla J.: Pojęcie kompetencji kluczowych w Podstawie programowej. „Nauczyciel i Szkoła” 2010, nr 1-2.

Goćkowski J., Machowska K.M.: Społeczeństwo wiedzy a społeczeństwo informatyczne. W: Społeczeństwo informatyczne. Szansa czy zagrożenie. Red. B. Chyrowicz. Lublin 2003.

Kompetencje kluczowe. Realizacja koncepcji na poziomie szkolnictwa obowiazkowego. Red. A. Smoczyńska. Warszawa 2005.

Łuczak A., Murdzek A.: Język polski. Między nami. Podręcznik dla klasy 6. Gdańsk 2017.

Matczak A.: Kwestionariusz kompetencji społecznych. Podręcznik. Warszawa 2001.

Morreale S.P., Spitzberg B.H., Barge J.K.: Komunikacja między ludźmi. Motywacja, wiedza i umiejętności. Tłum. D. Kobylińska, P. Izdebski, A. Jaworska. Warszawa 2007.

Nagajowa M.: ABC metodyki języka polskiego. Warszawa 1995.

Sęk H.: Spoleczna psychologia kliniczna. Warszawa 2004.

Sikorski M.: Kompetencje komunikacyjne nauczycieli. „Colloquium Wydziału Nauk Humanistycznych i Społecznych" 2010, nr 2.

Sternal E.: Kompetencje społeczne w obliczu przemian społeczno-gospodarczych. „Przegląd Pedagogiczny" 2014, nr 2.

Sztejnberg A.: Komunikacyjne środowisko nauczania i uczenia się. Wrocław 2004.

Zacher L.W.: Od społeczeństwa informacji do spoteczeństwa wiedzy. Spoteczeństwo informacyjne. Wizja czy rzeczywistość?. Kraków 2004.

Żuchowska W.: Do czego dydaktykom potrzebne jest pojęcie kompetencji. „Nowa Polszczyzna” 1999 , nr 1.

\section{Źródła internetowe}

Kwestionariusz ankiety. https://centrumwspieraniarodzin.pl/images/uploads/Zalacznik 3 OPZ 1 Kwestionariusz\%20ankiety\%20kompetencji\%20spo\%C5\%82ecznych.pdf [data dostępu: 30.03.2020].

Podstawa programowa kształcenia ogólnego. https://podstawaprogramowa.pl/

Ustawa Prawo oświatowe. Dz.U., poz. 2248. https://www.prawo.vulcan.edu.pl/przegdok.asp?qdatprz $=$ akt\&qplikid=4186 [data dostępu: 30.03.2020].

Zalecenie Parlamentu Europejskiego i Rady z dnia 18 grudnia 2006 roku. Dz.U. L 394 z 30.12.2006. https://eur-lex.europa.eu/legal-content/PL/TXT/PDF/?uri=CELEX:32006H0962\&from=EN [data dostępu: 30.03.2020].

Zalecenie Rady Unii Europejskiej z dnia 22 maja 2018 r. w sprawie kompetencji kluczowych w procesie uczenia się przez całe życie (2018/C189/01). https://eur-lex.europa.eu/legal-content/PL/ TXT/PDF/?uri=CELEX:32018H0604(01)\&from=EN [data dostępu: 30.03.2020]. 